Published in final edited form as:

Soc Sci Med. 2012 September ; 75(5): 932-939. doi:10.1016/j.socscimed.2012.04.028.

\title{
The association between parent's health and the educational attainment of their children
}

\author{
Jason D. Boardman, \\ University of Colorado Boulder \\ Kari B. Alexander, \\ University of Colorado Boulder \\ Richard Miech, \\ University of Colorado Denver \\ Ross MacMillan, and \\ University of Minnesota \\ Michael Shanahan \\ University of North Carolina
}

\section{Abstract}

In this paper we compare the educational attainment of adults who had relatively unhealthy parents when they were adolescents to those whose parents were relatively healthy during this time of their lives. We use data from the National Longitudinal Study of Adolescent Health $(n=13,556)$ to show that U.S. adolescents whose parents described their health as "fair" or "poor" at Wave 1 of the study were more likely to drop out of high school compared to those whose parents reported better levels of health. We do not observe any association between parental health and the likelihood of attending college among those who graduated from high school, however we do show that completing college (among college attendees) is more likely among those whose parents reported better health when they were adolescents. This association persists despite a wide range of statistical controls including socioeconomic status of the household, the physical and mental health status of the respondent, the grade point average of the respondent, the health behaviors of parents, as well as parental time investment. These findings add an important intergenerational component to research on the relationship between socioeconomic status and health.

\section{Keywords}

Education; intergenerational transmission; health; family; U.S.A.

\section{(C) 2012 Elsevier Ltd. All rights reserved.}

Address all correspondence to: Jason D. Boardman, University of Colorado, Institute of Behavioral Science, 1440 15th Street, Boulder, CO 80309-0483 ph: 303-492-2146; fx: 303-492-2151. boardman@ colorado.edu.

Publisher's Disclaimer: This is a PDF file of an unedited manuscript that has been accepted for publication. As a service to our customers we are providing this early version of the manuscript. The manuscript will undergo copyediting, typesetting, and review of the resulting proof before it is published in its final citable form. Please note that during the production process errors may be discovered which could affect the content, and all legal disclaimers that apply to the journal pertain. 


\section{Introduction}

The relationship between socioeconomic status (SES) and health is a central focus of epidemiology, public health, sociology, psychology, and demography. This large and diverse body of work has yielded consistent evidence that various aspects of SES including education, income, wealth, occupation, and employment status are all associated with physical health and mortality (Montez \& Hayward, 2011; Rogers et al., 2000). Nevertheless, debates continue to center around the most appropriate operationalization of SES (Braveman et al., 2010), the functional form of the SES-health association (Adler et al., 1999), the level at which these associations are structured (Diez-Roux, 2001), and the causal nature of this observed association (Smith, 1999). To date, however, the bulk of this research has examined the SES-health association within a single generation; the health of an individual (whether cross sectional or longitudinal) is assessed as a function lifetime socioeconomic position or economic attainment in adulthood is modeled as a function of childhood health conditions (Case et al., 2005; Hayward \& Gorman, 2004; Link \& Phelan, 1995). Very little work has examined the association between SES and health across generations within families (Andrew \& Ruel, 2010) and virtually no work has assessed the extent to which the presence of an ill parent is associated with educational attainment in young adulthood.

\section{Parental Health, availability, and changing roles}

Why would the presence of unhealthy parents interfere with the educational outcomes of their children? Our review of the literature suggests three possibilities: a) reduced availability of parents; b) associations between parental health and offspring health; and c) intergenerational transmission of socioeconomic status. Previous research has shown that parental involvement is strongly associated with student achievement (Desimone, 1999). Children with parents who are more involved with their school and social lives tend to have better educational and economic outcomes as adults compared to those whose parents are not involved with their schooling (Auerbach, 1989; Hill \& Taylor 2004). Unhealthy parents may be less able or have less time to dedicate to shared activities with their children such as helping with homework, discussing school issues, or even going shopping (Stein et al., 2007). As such, children may have less time to dedicate to school-related activities such as homework compared to their peers with relatively healthy parents. The imposition of new and time consuming roles generally focuses on adults caring for elderly parents (Finley, 1989), but the same functional role may be imposed upon children when their parents are ill at younger ages. This association is evident among children from single-headed households who have significantly lower grade point averages (GPA) compared to those from households in which both parents are present (Heard, 2007). If this process is cumulative in nature, then relatively small associations may become large enough to compromise the probability that a child will attain educational skills that lead to timely graduation, success in school, and ultimately transitions to post-secondary education.

\section{Intergenerational transmission of health and health behaviors}

It is also possible that the association between parental health and the educational attainment of their children is due to intergenerational transmission of health status; relatively healthy parents tend to have relatively healthy kids. Researchers have demonstrated fairly robust familial correlations for self-rated health of which roughly one-third is believed to be due to common genetic factors (Johnson and Krueger, 2005). Because of this strong familial association, having a healthy parent may be a proxy for the health status of the child. In which case having an unhealthy parent may not be associated with one's educational outcomes directly, but rather indirectly through their own health which has been consistently linked to the likelihood of on time educational attainment (Case et al., 2005; Currie and 
Stabile, 2003; Smith, 1999). Likewise, if children with an unhealthy parent find themselves in the role caregiver, this role may increase levels of stress and increase the risk of anxiety and depression (Armistead et al., 1995; Pederson and Reverson, 2005; Worsham et al., 1997). Compromised mental health status may make it difficult for students to complete high school, enroll in, or complete college (Baus et al., 2005).

Similarly, if parents have poor nutritional habits, lead a sedentary lifestyle, and/or smoke regularly then these factors will be associated with their health. Pampel et al. (2010) review the literature on education and health behaviors and show that those with less than 12 years of education are more likely than those with a college education to smoke, to be inactive, and to be obese. This is supported by recent research by Stringhini et al. (2010) who show that the association between SES and mortality is largely due to health behavior differences across the groups (see Jha et al., 2006 for similar results). Mirowsky and Ross (2003) contend that different dimensions of education (e.g. problem solving skills, self-efficacy) coalesce to bring about a kind of "learned effectiveness" that promotes healthy lifestyle choices. Therefore, parental health behaviors may capture a unique aspect of their educational background that may be associated with their children's likelihood of completing different levels of schooling.

\section{Intergenerational transmission of socioeconomic status}

It is also possible that parental health is linked to the educational attainment of their children because of the strong association between health and education (Mirowsky and Ross, 2003) within a generation as well as the limits on intergenerational social and educational mobility in the United States (Beller and Hout, 2006). That is, poor parental health may simply be a proxy for low parental educational levels. Haas (2006) has shown that a substantial portion of the association between parental education and offspring education operates through offspring health. Similarly, parental health may also be associated with the level of socioeconomic resources available to parents which are clearly associated with the subsequent educational attainment of their children. Smith (2004) shows that adults who experience a health shock such as a sudden disability or major illness have significantly lower earnings compared to comparable adults who did not experience this same shock. Similarly, French (2005) shows that adults with chronically poor health spend a greater share of their disposable income on health care compared to adults in better health. Both mechanisms may compromise the resources available to parents to support their children's educational needs.

\section{Health as an indicator of social status}

Finally, it is also possible that we may continue to see an association between parental health and the educational outcomes of their children that exists above and beyond statistical adjustments for parental education, income, health behaviors, parental time investment, and high school GPA. It is most likely that this residual association will be quite small and does not necessarily mean that parental health causes educational complications or delays. That is, the health of families may be best characterized as a "marker for social stratification" (Harris 2010: 17) rather than a determinant of education, per se. This 'integrative approach' described by Harris (2010) stresses the comprehensive and interactive nature of economic factors, health behaviors, and life chances. The movement away from the causality dimension of the health-SES-health association is best summarized by Bourdieu's (1990) notion of 'habitas' in which individuals derive meaning and practice a lifestyle that is both part of their social world but also actively reproduces their social world. Others have pointed out that health lifestyles denote a "set of social practices" (Frohlich et al., 2002:784) that are deeply embedded in social structures and that these health lifestyles give important clues 
about the way in which social inequality and health are reproduced and reinforce one another. Therefore, it is possible that poor parental health is a unique way of assessing aspects of habitas that is part of a complex "system of durable, transposable dispositions" (Bourdieu, 1990:53)

\section{METHODS}

\section{Data}

All data in these analyses are drawn from the National Longitudinal Study of Adolescent Health (Add Health), a study that examines health and health-related behaviors among a nationally representative sample of U.S. adolescents who were initially in the seventh through twelfth grades (Harris, 2003). In 1994, roughly 90,000 adolescents from 134 schools completed questionnaires about their daily activities, health-related behaviors, and basic social and demographic characteristics. A subset of respondents and their parents were then followed up with in-home interviews (Waves 1-4) with more detailed questions across a number of important domains. Wave 4 was conducted in 2008 and early 2009 when the sampled individuals were in early adulthood. The data for this analysis is limited to those adolescents whose parents responded to the parental questionnaire and provided valid responses to questions related to socioeconomic status and health. Of the 15,702 young adult respondents remaining in Wave 4, 2,141 either did not have a parent questionnaire completed in Wave 1 or did not have valid data for parent self-rated health. In total, our analysis uses 13,556 respondents. Although these are anonymous data, we have approval for our storage of data (security plan) from the IRB/HRC board at Colorado University, Boulder.

\section{Measures}

Table 1 presents descriptive statistics by parental health status. A description of each variable is provided below. Respondent education was measured in Wave 4 and captures the highest level of education to date for the young adult. Age of parent is the age of the responding parent at the time of the Wave 1, in home survey. Self-rated health is assessed similarly for parents and respondents who were asked "In general, how is your health?" Responses included "Excellent", "Very good", "Good", "Fair" or "Poor" and values ranged from 5 to 1 . While responses to self-rated health items are often different for different social groups (Finch et al., 2002; Prokopczyk et al., 2011), and may capture more of a world view than simply health-related symptoms (Boardman, 2004), self-rated health remains a valid and reliable measure of current health status (Idler, 2006). As with much of the research in this area, we use "Fair" and "Poor" to characterize poor health (Idler and Angel, 1990).

Respondent depression is assessed with a response to the frequency with which respondents have had the following in the past 12 months: a) moodiness; b) frequent crying; c) fearfulness; d) trouble relaxing; e) trouble falling asleep or staying awake; and f) poor appetite. Responses ranged from 0 "Never" to 4 "Everyday." Values were averaged across the six items for a measure of depression at wave $1($ alpha $=.73)$. We also include a statistical control for the total number of children in the household at the time of the Wave 1 interview. Relationship status uses a dummy variable coded 1 for parents who reported being single at the time of the interview and 0 for married couples. We also control for the age (wave 4 in years), gender, and race/ethnicity of the respondent.

Other statistical controls include grade point average, parental time, health behaviors, parental education, and income. We use two sources of information for grade point average. First, the Adolescent Health and Academic Achievement Study (conducted during 2001 and 2002) appended transcript data for roughly 12,000 respondents from the original Add Health sample. Using these records, student's objective grade point averages were calculated based 
on their English, math, history, and science classes. Of our 13,556 respondents, a total of 9,276 provided objective GPA scores. For 4,110 respondents we used self-reported values from the in home study for the same core courses. Others have shown that students tend to report slightly higher GPA values, but the two are highly correlated and the use of the selfreported measures does not increase the risk of bias (Cassady, 2001). We examine time spent with parents using a measure of shared activities. In Wave 1, respondents were asked whether their resident parental figure participated in various activities with them in the previous four weeks. The possibilities included shopping, playing a sport, attending a religious service, talking about dating or parties, attending events, talking about serious problems, talking about grades, working on a project for school, talking about other school issues. We define parental involvement as the sum of the number of items answered in the affirmative by the respondent (alpha $=.95$ ). Parental health behaviors are assessed with two self-reported indicators. In Wave 1, parents who answered yes to the question, "Do you a smoke?" were labeled "smokers". If the biological mother or father was identified as "obese" by the parental respondent and lived in the household then the adolescent is considered to have had an obese parent. Parental education describes the highest degree attained by the parent at the time of the Wave 1 interview. Household income is measured by response to the question "About how much total income, before taxes did your family receive in 1994?" Responses were recorded in dollars and the logged value was used as a control in the multivariate analyses.

We use logistic regression models in order to gauge the association between parental health and various levels of educational attainment of their children. We do this separately for high school completion, college enrollment among those who completed college, and college matriculation for those who attended college. Missing data were evident for the measures of GPA (170), shared time (195), respondent self-rated health (9), respondent depression (8), and household income (1658). Because of the issues involved with either mean imputation or listwise deletion (Little and Rubin, 2002), we use multiple imputation techniques with the mi commands in STATA 12.0 to estimate our regression models discussed below. We use 10 imputations which is believed to be an adequate number of imputed data sets for these purposes (Graham et al., 2007).

\section{RESULTS}

Table 1 presents descriptive statistics for all variables used in the analysis by parental health status. The primary goal of this paper is summarized by the results in the first and fourth rows of this table. Offspring of unhealthy parents (13\%) were more than twice as likely as those with healthy parents (6\%) to drop out of high school and nearly one-half as likely to have attained a college degree (18\% compared to 34\%). This association was statistically significant (Chi-square $=301.54(\mathrm{df}=3), \mathrm{p}<.0001)$ and set the stage for the remainder of the analyses. That is, why did we see this marked association between the health of parents and the educational outcomes of their children? Further examination of Table 1 shows that compared to unhealthy parents, healthy parents were significantly younger, had fewer children in the household, were less likely to be single, less likely to smoke, less likely to be obese, more likely to hold a college degree, far less likely to have dropped out of high school, and made significantly more money on an annual basis. Likewise, respondents with healthy parents were more likely to be non-Hispanic and white, have higher GPAs, spend more time with their parents, and report better physical and mental health. All of these associations were statistically significant and taken together it suggests that the observed association between parental health and offspring education may be confounded with some, none, or all of these factors. The multivariate analyses in Tables 2-4 were designed to explore these possibilities. 
Table 2 presents results from three logistic regression models in which the likelihood of completing high school was predicted with parental health status at Wave 1. As shown in Model 1, net of the fairly comprehensive list of controls, respondents with unhealthy parents were nineteen percent less likely $(\mathrm{b}=-.203, \mathrm{OR}=.816, \mathrm{p}<.05)$ to graduate from high school compared to those with healthy parents. Model 2 includes a statistical control for time spent with parents. Respondents were more likely to have completed high school if their parents spent larger amounts of time with them while they were teenagers but this control had virtually no influence on the estimate for poor parental health. This suggests that parental health status is not associated with high school graduation because of the availability of parents to assist with homework or other school-related activities that may increase the likelihood of graduating. The final model (Model 3) examines the possibility that parental health is simply a marker of a healthy lifestyle which may confer educational returns because success in school denotes a component of a relatively healthy lifestyle (Pampel et al. 2010). Parental smoking status $(b=-.396, p<.001)$, but not parental obesity status, was strongly associated with the likelihood that a student will complete high school and these controls reduced the residual association by roughly ten percent, but parental health status was still associated with at $16.5 \%$ reduction in the relative odds of high school completion $(\mathrm{b}=-.180, \mathrm{OR}=.835, \mathrm{p}<.05)$.

A different story emerges when considering college attendance. While the direction of the association was negative $(b=-.107, p<.126)$ the estimate was not statistically dissimilar from zero and the coefficient was roughly one-half the size of the coefficient for high school completion. This is important because the two outcomes denote fundamentally different educational processes; completion of a degree compared to enrollment in a post-secondary setting in which a critical aspect of the latter is the availability of financial resources to pay for tuition, housing, etc. In other words, if parental health status influenced educational attainment because it affected financial resources, this association should be particularly strong for entrance in to college which requires sizable financial resources but this was not the case. This distinction (graduation vs. enrollment) is further illustrated in Table 4 in which the outcome is college graduation among those who attended college. Again, when considering completion of the degree, we continue to see a negative and statistically significant association for poor parental health status $(b=-.208, \mathrm{OR}=.812, \mathrm{p}<.05)$ despite the comprehensive list of statistical controls. As with high school graduation, the mechanism for this association does not appear to be the availability of the parent which, while strongly associated with successful college matriculation $(b=.047, p<.001)$, did very little to change the residual association between poor parental health and the likelihood of graduating from college among college attendees. And, as with high school completion, the health related behaviors of parents at Wave 1 were strongly associated with the likelihood that their children will graduate from college by Wave 4 , and these controls explained an additional seventeen percent of the residual association between parental health status and college graduation.

\section{DISCUSSION}

Health disparities have persisted into the $21^{\text {st }}$ century despite universal social safety nets such as Medicaid and Medicare; those with higher education, income, wealth, and occupational status tend to enjoy healthier and longer lives (Cutler \& Lleras-Mavey, 2008; Marmot, 2004). The bulk of the existing literature on this topic has explored these associations within one generation but as shown here, the health of the one generation may be associated with the educational attainment of the next. In the broader theoretical debate of whether poor health leads to lower SES or vice-versa, this study's results shed light on an understudied aspect of selection. Poor health may impair the educational attainment of individuals (a key component of SES), albeit the poor health of their parents. To the extent 
that poor health is transmitted within families, the association between poor health and educational attainment may become stronger with each successive generation within families. Such a process would lead to a substantial concentration of poor health in the lower socioeconomic strata. This process would be difficult to detect with standard intragenerational analyses.

What may explain the association between parents' health and their children's educational advancement? Several factors warrant future research. It is possible that poor parental health creates important role changes for children that compromise their success in school. We adjusted for GPA and time spent with parents but this association can be tested in an additional way. To further explore this possibility, we estimated additional models in which we allowed the estimates for parental health status to vary as a function of family composition measures. Specifically, we estimated separate models comparable the final models of Tables 2-4 in which we specified an interaction between poor parental health and a) single parent status, b) only child status, and c) oldest child status. Our logic was as follows: if the key mechanism linking parental health status to limited educational outcomes is decreased availability then the association between parental health and education should be stronger among children of single parents (there is no other adult around to help out), those who are the only children (they cannot share the new responsibilities with anyone else), or the oldest child (they need to take care of themselves and their younger siblings). In all cases, we did not find any significant interactions between parental health and these factors (these results are available upon request). This provides additional evidence that the association does not necessarily operate through parental availability.

It is also possible that the association between parental health and offspring education is due to unobserved factors that are shared by family members that cause both health and education. We see two plausible mechanisms. First, the source of the covariance between health and SES may be genetically oriented. Researchers have used twin and sibling studies to examine the extent to which genetic factors associated with physical health are the same as those related to SES. With regards to this study, there is consistent evidence that genetic factors are associated with physical health (Johnson and Krueger, 2005), health related behaviors (Boardman, 2009), and SES (Nielsen, 2006). Each phenotype has evidenced heritability estimates that range from .4-.7 suggesting that a large proportion of the total variance is due to additive genetic factors. More importantly, because these factors are highly intercorrelated and because each is highly heritable, some have tested the possibility that the genes linked to one phenotype are common to all; their correlation in the population may be due to a common genetic source rather than one causing the other. In one of the largest studies done on this issue, Silventoinen et al., (2004: 544) use two large twin registries in Minnesota and Finland and show that the correlation between body height and educational attainment is "overwhelmingly due to the correlation of the shared environmental factors affecting these two traits." That is, while genetic factors may influence both health and SES, there is little evidence that the association between these two factors is due to common genetic origins. Nevertheless, genes linked with cognitive skills could prevent individuals from learning about or implementing healthy lifestyle choices and could also prevent individuals from succeeding economically (Fuchs, 1982), which may produce health complications in early life. Although some have found evidence that this is not driving educational disparities in health (Link et al., 2008) it is nevertheless important to consider a variety of different explanations for the remaining associations shown in Model 3 of Tables 2 and 4.

Second, it is also possible that more distal social factors structure specific contexts in which parental health and their children's education simply co-occur; in other words they are derived from the same complex social structure rather that one causing the other. This 
perspective is critical for the interpretation of our results because it suggests that parental health may provide an important clue about the social contexts in which health and education are both practiced which paints a more comprehensive picture of offspring's social class than education or income alone. As described above, once we have adjusted for the more proximate factors that may link poor parental health to the educational outcomes of their children, the remaining association may tap in to the process of social distinction in which health behaviors and educational outcomes are both part of the same lifestyle (Bourdieu, 1984). This helps us to understand why no single measure that was correlated with both parental health and offspring educational attainment fully accounted for the observed association between the two factors for high school completion and college graduation. Evidence for this perspective was the strong association between parental smoking and obesity status and the likelihood that their children will graduate from college. In both cases, children were roughly twenty percent less likely to complete college compared to similar students whose parents demonstrated more salutary behaviors. Further, these controls reduced the remaining association between parental health and college graduation by nearly one-fifth suggesting that health lifestyles may be part of the link between parental health and college graduation.

\section{LIMITATIONS}

Despite the strengths of the Add Health study design including a nationally representative and longitudinal study of a cohort of young adults, there are important limitations that should be considered when evaluating the results of our study. For example, we have very limited information about the parents of the respondents. The parent data contain fairly crude indicators of health and no information about change in health over time, no information about the onset of "ill health" or specific morbidities, and no information about change in parental health behaviors over time. We also have no information about change in the socioeconomic status of parents for Waves 3 and 4 of the Add Health study in which researchers turned their attention to the respondents and very little information was assessed about their parents. While we adjust for family income and parental education which are clearly associated with college matriculation (Turley et al., 2006), we were not able to adjust our statistical models for family wealth. Others (Conley, 2001) have shown a significant influence of total net worth that operates above and beyond household income, occupational status, and educational outcomes of the head of the household. While this same research indicates that the effects of net worth appear to be smaller than the effects of parental education it is still important to consider this omission when interpreting these results.

Furthermore, nearly thirteen years have passed between the assessment of parental health status and our assessment of years of completed education. We control for a variety of risk factors but we do not fully characterize the different trajectories that individual's may take to obtain a college degree. We adjust for valid and reliable measures of known risk factors but there are likely to be other unobserved characteristics of respondents that may account for the residual association in our models. For example, our measure of parental time is obtained at Wave 1 and others have shown that parental support is a very strong indicator of a young adult's decision to continue in college (Bank et al.,1990) and parental support throughout college is a key factor in children's college success (reviewed in Seymour and Hewitt, 1997). Although we control for parental time at Wave 1, we do not have any information about the time spent with students while they were in college. This information would enhance this aspect of our study.

Finally, it is also important to characterize the magnitude of the associations that we present in Tables 2-4. These regression models report the statistical significance, which is only an indication about the probability that the coefficient might be equal to zero in the population. 
It does not give us any indication about the relative importance of this factor for overall matriculation rates. To illustrate this point we calculated probabilities for the three educational outcomes based on the final regression models in Tables 2-4. Using the margins post-estimation command in Stata 12.0 and setting the remaining coefficients at their averages, we calculated the probability of graduating from college among college attendees to be .364 for those with healthy parents and .325 for those with unhealthy parents. These estimates are shown in Table 5. To better assess this magnitude of this difference, consider that the probability of completing college (among college attendees) for those whose parents have a college degree is .483 compared to .323 for those whose parents did not complete college (these results are not presented in the table). This table also demonstrates how to recover the regression coefficients shown in Table 4 and it highlights the potential difference between statistical and substantive significance. This is particularly important when considering the relatively small difference in the estimated probability of graduating from high school for students whose parents are healthy $(\mathrm{pr}=.964)$ compared to those whose parents are unhealthy $(\mathrm{pr}=.957)$. However, it is also important to consider that this small difference in the probability of graduating from high school as a function of parental health involves a very large population of high school students in the United States. According to the US Census, there were 16,574,000 individuals enrolled in grades 9-12 in the year 2010 (US Census, 2010). If we consider that $16.6 \%$ of our sample came from homes in which a parent reported ill health, then roughly 2.75 million students are from homes with an unhealthy parent. Given the probabilities from Table 5, this suggests that 2.63 million of these 2.75 million students will graduate from high school but this number increases to 2.65 million if their parents were healthy. In total, we estimate that 19,225 students may be significantly more likely to complete high school if the health of their parents were to increase. These are obviously very crude estimates and they assume that the underlying association is causal in nature, but it is important to note the relative and absolute implications of this association vis-à-vis the wellbeing of populations.

\section{CONCLUSION}

Who gets ahead in the U.S. has long been of central interest to sociologists. While ambition and hard work certainly play a key role in socioeconomic advancement so too do factors outside of the individual's control, such as parents' education and income. The results of this study indicate that parents' health is associated with the status attainment of their children and that this association operates somewhat independently of other risk factors. This complex set of associations has received little recognition to date. In terms of policy recommendations our results indicate support for the notion that parental health should be included in the assessment of individual progress within educational settings. Thus, although individualized educational programs are generally limited to students with diagnosed learning disabilities, parental health information could be obtained at enrollment time that may provide teachers and administrators with a more nuanced understanding of all students' home lives. We are not able to identify a causal role between parental health and educational outcomes among children but the general association suggests that it is possible that improving the health of parents may also have important educational returns for their children. As such, one spillover of policies to improve the health of the population is the possibility that educational attainment of the population will increase as well.

\section{Acknowledgments}

This research uses data from Add Health, a program project designed by J. Richard Udry, Peter S. Bearman, and Kathleen Mullan Harris, and funded by a grant P01-HD31921 from the Eunice Kennedy Shriver National Institute of Child Health and Human Development, with cooperative funding from 23 other federal agencies and foundations. Special acknowledgment is due Ronald R. Rindfuss and Barbara Entwisle for assistance in the original design. Persons interested in obtaining data files from Add Health should contact Add Health, Carolina Population 
Center, 123 W. Franklin Street, Chapel Hill, NC 27516-2524 (addhealth@unc.edu). No direct support was received from grant P01-HD31921 for this analysis. This paper is part of larger studies funded by the National Institute of Child Health and Human Development (R01HD060726 and R01HD061622). Research funds were also provided by the NIH/NICHD funded CU Population Center (R24HD066613).

\section{References}

Adler NE, Ostrove JM. Socioeconomic status and health: what we know and what we don't. Annals of the New York Academy of Sciences. 1999; 896:3-15. [PubMed: 10681884]

Armistead L, Klein K, Forehand R. Parental physical illness and child functioning. Clinical Psychology Review. 1995; 15(5):409-422.

Andrew M, Ruel E. Intergenerational health selection in wealth: A first look at parents' health events and inter vivos financial transfers. Social Science Research. 2010; 39(6):1126-1136.

Auerbach ER. Toward a social-contextual approach to family literacy. Harvard Educational Review. 1989; 59(2):165-181.

Bank BJ, Slavings RL, Biddle BJ. Effects of peer, faculty, and parental influences on students' persistence. Sociology of Education. 1990; 63:208-225.

Beller E, Hout M. Intergenerational social mobility: the united states in comparative perspective. The Future of Children. 2006; 16(2):19-36. [PubMed: 17036544]

Baus R, Dysart-Gale D, Haven P. Caregiving and social support: a twenty-first century challenge for college students. Communication Quarterly. 2005; 53(2):125-142.

Boardman JD. State-level moderation of genetic tendencies to smoke. American Journal of Public Health. 2009; 99:480-6. [PubMed: 19150910]

Boardman JD. Health pessimism among black and white adults: the role of interpersonal and institutional maltreatment. Social Science \& Medicine. 2004; 59:2523-2533. [PubMed: 15474206]

Bourdieu, P. Distinction: a social critique of the judgment of taste. Routledge; London: 1984.

Bourdieu, P. The logic of practice. Stanford University Press; Stanford, CA: 1990.

Braveman PA, Cubbin C, Egerter S, Williams DR, Pamuk E. Socioeconomic disparities in health in the United States: what the patterns tell us. American Journal of Public Health. 2010; 100(Supplement 1):S186-96. [PubMed: 20147693]

Case A, Fertig A, Paxson C. The lasting impact of childhood health and circumstance. Journal of Health Economics. 2005; 24(2):365-389. [PubMed: 15721050]

Cassady JC. Self-reported GPA and SAT: A methodological note. Practical Assessment, Research, and Evaluation. 2001; 7(12):1-3.

Conley D. Capital for college: parental assets and postsecondary schooling. Sociology of Education. 2001; 74(1):59-72.

Currie J, Stabile M. Socioeconomic status and health: why is the relationship stronger for older children? American Economic Review. 2003; 93(5):1813-1823.

Cutler, DM.; Lleras-Muney, A. Education and health: evaluating theories and evidence. In: Schoeni, RF.; House, JS.; Kaplan, GA.; Pollack, H., editors. Making Americans Healthier: Social and Economic Policy a Health Policy. Russell Sage Foundation; New York: 2008. p. 29-60.

Desimone L. Linking parent involvement with student achievement: Do race and income matter? The Journal of Educational Research. 1999; 93(1):11-30.

Diez-Roux AV. Investigating neighborhood and area effects on health. American Journal of Public Health. 2001; 91:1783-1789. [PubMed: 11684601]

Finch BK, Hummer RA, Reindl M, Vega WA. Validity of self-rated health among Latino(a)s. American Journal of Epidemiology. 2002; 155(8):755-9. [PubMed: 11943694]

Finley, Nancy J. Theories of family labor as applied to gender differences in caregiving for elderly parents. Journal of Marriage and Family. 1989; 51:79-86.

French E. The effects of health, wealth, and wages on labour supply and retirement behaviour. Review of Economic Studies. 2005; 72:395-427.

Frohlich KL, Corin E, Potvin L. A theoretical proposal for the relationship between context and disease. Sociology of Health \& Illness. 2002; 23(6):776-797. 
Fuchs, VR. Time preference and health: an exploratory study. In: Fuchs, VR., editor. Economic Aspects of Health. University of Chicago Press; Chicago: 1982. p. 93-120.

Graham JW, Olchowski AE, Gilreath TD. How many imputations are really needed? Some practical clarifications of multiple imputation theory. Prevention Science. 2007; 8:206. [PubMed: 17549635]

Haas SA. Health selection and the process of social stratification: the effect of childhood health on socioeconomic attainment. Journal of Health and Social Behavior. 2006; 47:339-354. [PubMed: 17240924]

Harris, K. The national longitudinal study of adolescent health (Add Health), Waves I \& II, 1994-1996; Wave III, 2001-2002. Carolina Population Center, University of North Carolina at Chapel Hill; Chapel Hill, NC: 2003. machine-readable data file and documentation

Harris K. An integrative approach to health. Demography. 2010; 47(1):1-22. [PubMed: 20355681]

Hayward MD, Gorman BK. The long arm of childhood: the influence of early-life social conditions on men's mortality. Demography. 2004; 41:87-107. [PubMed: 15074126]

Heard HE. The family structure trajectory and adolescent school performance: differential effects by race and ethnicity. Journal of Family Issues. 2007; 28(3):319-354.

Hill NE, Taylor LC. Parental school involvement and children's academic achievement: pragmatics and issues. Current Directions in Psychological Science. 2004; 13:161.

Idler E. In sickness but not in health: self-ratings, identity, and mortality. Journal of Health and Social Behavior. 2006; 45(3):336-356. [PubMed: 15595511]

Idler EL, Angel R. Self-rated health and mortality in the NHANES-I epidemiological follow-up study. American Journal of Public Health. 1990; 80:446-452. [PubMed: 2316767]

Jha P, Peto R, Zatonski W, Boreham J, Jarvis MJ, Lopez AD. Social inequalities in male mortality, and in male mortality from smoking: indirect estimation from national death rates in England and Wales, Poland, and North America. The Lancet. 2006; 368:367-70.

Johnson W, Krueger RF. Predictors of physical health: Toward an integrated model of genetic and environmental antecedents. Journals of Gerontology: Series B. 2005; 60:42-52.

Link BG, Phelan JC. Social conditions as fundamental causes of disease. Journal of Health and Social Behavior. 1995; (Special issue):80-94. [PubMed: 7560851]

Link BG, Phelan JC, Miech R, Westin EL. The resources that matter: fundamental social causes of health disparities and the challenge of intelligence. Journal of Health and Social Behavior. 2008; 49:72-91. [PubMed: 18418986]

Little, RJA.; Rubin, DB. Statistical Analysis with Missing Data, Second Edition. Whiley-InterScience; Hoboken, New Jersey: 2002.

Marmot, M. Status Syndrome: How Social Standing Affects Our Health and Longevity. Henry Holt \& Company; 2004.

Mirowsky, J.; Ross, CE. Education, Social Status and Health. Aldine De Gruyter; New York: 2003.

Montez, JK.; Hayward, MD. Early life conditions and later life mortality. In: Rogers, Richard G.; Crimmins, Eileen M., editors. the International Handbook of Adult Mortality. Springer Publishers; NY: 2011. p. 185-204.Chapter 9

Nielsen F. Achievement and ascription in educational attainment: Genetic and environmental influences on adolescent schooling. Social Forces. 2006; 85:193-216.

Pampel FC, Krueger PM, Denney JT. Socioeconomic disparities in health behaviors. Annual Review of Sociology. 2010; 36:349-370.

Pederson S, Revenson TA. Parental illness, family functioning, and adolescent well-being: a family ecology framework to guide research. Journal of Family Psychology. 2005; 19(3):404-419. [PubMed: 16221021]

Prokopczyk H, Freese J, Hauser RM. Using anchoring vignettes to assess group differences in general self-rated health. Journal of Health and Social Behavior. 2011; 52(2):246-61. [PubMed: 21673148]

Rogers, RG.; Hummer, RA.; Nam, CB. Living and dying in the USA: behavioral, health, and social differentials of adult mortality. Academic Press; San Diego: 2000. 
Seymour, E.; Hewitt, NM. Talking about leaving: why undergraduates leave the sciences. Westview Press; Boulder, CO: 1997.

Silventoinen K, Krueger RF, Bouchard TJ, Kaprio J, McGue M. Heritability of body height and educational attainment in an international context: comparison of adult twins in Minnesota and Finland. American Journal of Human Biology. 2004; 16:544-555. [PubMed: 15368602]

Smith JP. Healthy bodies and thick wallets: the dual relation between health and economic status. Journal of Economic Perspectives. 1999; 13:144-66. [PubMed: 15179962]

Smith JP. Unraveling the SES-health connection. Population and Development Review. 2004; 30(Supplement):108-132. Aging, Health, and Public Policy.

Stein JA, Rotherham-Borus MJ, Lester P. Impact of parentification on long-term outcomes among children of parents with HIV/AIDS. Family Process. 2007; 46(3):317-333. [PubMed: 17899856]

Stringhini S, Sabia S, Shipley M, Brunner E, Nabi H, Kivimaki M, Singh-Manoux A. Association of socioeconomic position with health behaviors and mortality. JAMA. 2010; 303:1159-66. [PubMed: 20332401]

Turley R, Lopez N, Santos M, Ceja C. Social origin and college opportunity expectations across cohorts. Social Science Research. 2006; 36(3):1200-1218.

US Census. [Accessed, February 9, 2012] Single grade of enrollment and high school graduation status for people 3 years old and over, by sex, age (single years for 3 to 24 years), race, and Hispanic Origin: October. 2010. http://www.census.gov/hhes/school/data/cps/2010/tables.html

Williams SJ. Theorising class, health, and lifestyles: can Bourdieu help us? Sociology of Health \& Illness. 1995; 17(5):577-604.

Worsham, NL.; Compas, BE.; Ey, S. Children coping with parental illness. In: Wolchik, SA.; Sandler, IN., editors. Handbook of children's coping: linking theory and intervention. Plenum Press; New York: 1997. p. 195-212. 


\section{Research Highlights}

- Having healthy parents is associated with an increased chance of graduating from high school and of completing college among those who attend college.

- This association exists despite differences in grade point average, family SES, family health behaviors, and parental time investment among adolescents with healthy and unhealthy parents.

- Possible explanations include household wealth, genetic factors, or other unobservable factors that structure both education and health within households. 
Table 1

Descriptive statistics by parental health status $(\mathrm{n}=13,556)$.

\begin{tabular}{|c|c|c|c|}
\hline & $\begin{array}{l}\text { Healthy } \\
\text { Parent }\end{array}$ & $\begin{array}{l}\text { Unhealthy } \\
\text { Parent }\end{array}$ & pr. $<$ \\
\hline \multicolumn{4}{|l|}{ Respondent education } \\
\hline Less than high school & 0.06 & 0.13 & 0.000 \\
\hline High school only & 0.16 & 0.23 & \\
\hline Some college & 0.44 & 0.46 & \\
\hline College+ & 0.34 & 0.18 & \\
\hline Age of parent & $\begin{array}{l}41.66 \\
(6.30)\end{array}$ & $\begin{array}{l}43.68 \\
(8.43)\end{array}$ & 0.040 \\
\hline Total number children in $\mathrm{HH}$ & $\begin{array}{c}2.54 \\
(1.34)\end{array}$ & $\begin{array}{c}2.68 \\
(1.66)\end{array}$ & 0.027 \\
\hline Single parent household & 0.27 & 0.42 & 0.000 \\
\hline Male respondent & 0.48 & 0.45 & 0.007 \\
\hline Age of respondent (Wave 4) & $\begin{array}{l}28.35 \\
(1.77)\end{array}$ & $\begin{array}{l}28.59 \\
(1.73)\end{array}$ & 0.713 \\
\hline \multicolumn{4}{|l|}{ Respondent race/ethnicity } \\
\hline NH white & 0.59 & 0.43 & 0.000 \\
\hline NH black & 0.20 & 0.27 & \\
\hline Hispanic & 0.14 & 0.24 & \\
\hline Other race/ethnicity & 0.07 & 0.06 & \\
\hline GPA & $\begin{array}{l}2.66 \\
(.81)\end{array}$ & $\begin{array}{l}2.36 \\
(.82)\end{array}$ & 0.000 \\
\hline Time spent with parents & $\begin{array}{c}3.97 \\
(2.03)\end{array}$ & $\begin{array}{c}3.67 \\
(2.03)\end{array}$ & 0.000 \\
\hline Respondent poor physical health & 0.06 & 0.12 & 0.000 \\
\hline Respondent mental health & $\begin{array}{l}0.76 \\
(.56)\end{array}$ & $\begin{array}{l}0.81 \\
(.64)\end{array}$ & 0.026 \\
\hline Parent smokes in $\mathrm{HH}$ & 0.27 & 0.37 & 0.000 \\
\hline Parent obese in $\mathrm{HH}$ & 0.18 & 0.25 & 0.000 \\
\hline \multicolumn{4}{|l|}{ Parental education } \\
\hline Less than high school & 0.14 & 0.38 & 0.000 \\
\hline High school only & 0.30 & 0.29 & \\
\hline Some college & 0.31 & 0.24 & \\
\hline College + & 0.26 & 0.09 & \\
\hline Household income (ln) & $\begin{array}{l}3.63 \\
(.80)\end{array}$ & $\begin{array}{l}3.03 \\
(.91)\end{array}$ & 0.000 \\
\hline $\mathrm{N}$ & 11,629 & 1,927 & \\
\hline
\end{tabular}

Note: all data come from the National Longitudinal Study of Adolescent Health (Harris 2003). Two-tailed t-tests are used to compare the distribution of each variable by parental health status. Chi-square test of independence is used for multinomial variables such as race and respondent education. 
Table 2

Logistic regression estimates: the association between parental health and the likelihood of graduating from high school $(\mathrm{n}=13,556)$.

\begin{tabular}{|c|c|c|c|}
\hline & (1) & (2) & (3) \\
\hline Poor parental health & $\begin{array}{l}-0.203^{*} \\
(0.090)\end{array}$ & $\begin{array}{l}-0.200^{*} \\
(0.090)\end{array}$ & $\begin{array}{l}-0.180^{*} \\
(0.091)\end{array}$ \\
\hline Parent's age & $\begin{array}{c}0.024^{* * *} \\
(0.005)\end{array}$ & $\begin{array}{c}0.025^{* * *} \\
(0.005)\end{array}$ & $\begin{array}{c}0.022^{* * *} \\
(0.005)\end{array}$ \\
\hline Number of children in $\mathrm{HH}$ & $\begin{array}{l}-0.026 \\
(0.024)\end{array}$ & $\begin{array}{l}-0.023 \\
(0.024)\end{array}$ & $\begin{array}{l}-0.033 \\
(0.025)\end{array}$ \\
\hline Single parent household & $\begin{array}{c}-0.138^{+} \\
(0.083)\end{array}$ & $\begin{array}{c}-0.160^{+} \\
(0.083)\end{array}$ & $\begin{array}{l}-0.112 \\
(0.084)\end{array}$ \\
\hline Male respondent & $\begin{array}{l}-0.294^{* * * *} \\
(0.077)\end{array}$ & $\begin{array}{l}-0.255^{* *} \\
(0.078)\end{array}$ & $\begin{array}{c}-0.260^{* * * *} \\
(0.078)\end{array}$ \\
\hline Respondent's age & $\begin{array}{l}0.060^{* *} \\
(0.021)\end{array}$ & $\begin{array}{l}0.066^{* * *} \\
(0.021)\end{array}$ & $\begin{array}{l}0.066^{* *} \\
(0.021)\end{array}$ \\
\hline $\begin{array}{l}\text { Respondent's race [NH White] } \\
\text { NH Black }\end{array}$ & $\begin{array}{l}0.204^{*} \\
(0.094)\end{array}$ & $\begin{array}{l}0.193^{*} \\
(0.095)\end{array}$ & $\begin{array}{c}0.123 \\
(0.096)\end{array}$ \\
\hline Hispanic & $\begin{array}{l}0.389^{* * * *} \\
(0.104)\end{array}$ & $\begin{array}{l}0.384^{* * *} \\
(0.104)\end{array}$ & $\begin{array}{c}0.274^{* *} \\
(0.106)\end{array}$ \\
\hline Other & $\begin{array}{c}0.264 \\
(0.185)\end{array}$ & $\begin{array}{c}0.274 \\
(0.185)\end{array}$ & $\begin{array}{c}0.205 \\
(0.186)\end{array}$ \\
\hline $\begin{array}{l}\text { Parent's education }[<\mathrm{HS}] \\
\text { High school graduate }\end{array}$ & $\begin{array}{l}0.580 \text { *** } \\
(0.094)\end{array}$ & $\begin{array}{l}0.560 \text { *** } \\
(0.094)\end{array}$ & $\begin{array}{c}0.548^{* * *} \\
(0.094)\end{array}$ \\
\hline Some college & $\begin{array}{l}0.978^{* * *} \\
(0.107)\end{array}$ & $\begin{array}{c}0.946^{* * *} \\
(0.107)\end{array}$ & $\begin{array}{c}0.913^{\text {*** }} \\
(0.107)\end{array}$ \\
\hline College graduate & $\begin{array}{c}1.435^{* * *} \\
(0.162)\end{array}$ & $\begin{array}{c}1.383^{* * *} \\
(0.162)\end{array}$ & $\begin{array}{c}1.311^{* * * *} \\
(0.163)\end{array}$ \\
\hline Respondent poor health & $\begin{array}{l}-0.116 \\
(0.121)\end{array}$ & $\begin{array}{l}-0.085 \\
(0.121)\end{array}$ & $\begin{array}{l}-0.056 \\
(0.122)\end{array}$ \\
\hline Respondent mental health & $\begin{array}{c}-0.150^{*} \\
(0.062)\end{array}$ & $\begin{array}{c}-0.165^{* *} \\
(0.062)\end{array}$ & $\begin{array}{c}-0.149^{*} \\
(0.063)\end{array}$ \\
\hline Household income (ln) & $\begin{array}{c}0.364^{* * *} \\
(0.048)\end{array}$ & $\begin{array}{c}0.358^{* * *} \\
(0.048)\end{array}$ & $\begin{array}{c}0.355^{* * *} \\
(0.049)\end{array}$ \\
\hline Respondent GPA & $\begin{array}{l}1.331 \text { *** } \\
(0.050)\end{array}$ & $\begin{array}{c}1.316^{* * *} \\
(0.050)\end{array}$ & $\begin{array}{l}1.295^{* * *} \\
(0.051)\end{array}$ \\
\hline Time spent with parents & & $\begin{array}{c}0.089^{* * *} \\
(0.019)\end{array}$ & $\begin{array}{c}0.088^{* * *} \\
(0.019)\end{array}$ \\
\hline Parent smokes in $\mathrm{HH}$ & & & $\begin{array}{c}-0.396^{\text {**** }} \\
(0.078)\end{array}$ \\
\hline Parent obese in $\mathrm{HH}$ & & & $\begin{array}{c}0.005 \\
(0.096)\end{array}$ \\
\hline Intercept & $\begin{array}{c}-4.616^{* * *} \\
(0.637)\end{array}$ & $\begin{array}{c}-5.097^{\text {**** }} \\
(0.646)\end{array}$ & $\begin{array}{c}-4.668^{* * * *} \\
(0.653)\end{array}$ \\
\hline \multicolumn{4}{|l|}{ Standard errors in parentheses } \\
\hline \multicolumn{4}{|l|}{${ }^{+} p<.10$} \\
\hline${ }^{*} p<.05$ & & & \\
\hline
\end{tabular}


*** $p<.01$

*** $p<.001$ 
Table 3

Logistic regression estimates: the association between parental health and the likelihood of attending college among high school graduates $(n=12,548)$.

\begin{tabular}{|c|c|c|c|}
\hline & (1) & (2) & (3) \\
\hline Poor parental health & $\begin{array}{l}-0.107 \\
(0.070)\end{array}$ & $\begin{array}{l}-0.108 \\
(0.070)\end{array}$ & $\begin{array}{l}-0.098 \\
(0.070)\end{array}$ \\
\hline Parent's age & $\begin{array}{l}0.020^{* * * *} \\
(0.004)\end{array}$ & $\begin{array}{l}0.021^{* * *} \\
(0.004)\end{array}$ & $\begin{array}{l}0.019^{* * *} \\
(0.004)\end{array}$ \\
\hline Number of children in $\mathrm{HH}$ & $\begin{array}{c}-0.085^{* * *} \\
(0.017)\end{array}$ & $\begin{array}{c}-0.083^{* * * *} \\
(0.017)\end{array}$ & $\begin{array}{c}-0.090^{* * * *} \\
(0.017)\end{array}$ \\
\hline Single parent household & $\begin{array}{l}-0.024 \\
(0.060)\end{array}$ & $\begin{array}{l}-0.040 \\
(0.060)\end{array}$ & $\begin{array}{l}-0.011 \\
(0.061)\end{array}$ \\
\hline Male respondent & $\begin{array}{c}-0.398^{* * *} \\
(0.053)\end{array}$ & $\begin{array}{c}-0.356^{* * * *} \\
(0.053)\end{array}$ & $\begin{array}{c}-0.362^{* * * *} \\
(0.053)\end{array}$ \\
\hline Respondent's age & $\begin{array}{l}-0.033^{*} \\
(0.015)\end{array}$ & $\begin{array}{c}-0.029^{+} \\
(0.015)\end{array}$ & $\begin{array}{l}-0.029^{*} \\
(0.015)\end{array}$ \\
\hline $\begin{array}{l}\text { Respondent's race [NH White] } \\
\text { NH Black }\end{array}$ & $\begin{array}{l}0.358^{* * *} \\
(0.069)\end{array}$ & $\begin{array}{l}0.352^{* * * *} \\
(0.069)\end{array}$ & $\begin{array}{c}0.317^{* * * *} \\
(0.070)\end{array}$ \\
\hline Hispanic & $\begin{array}{l}0.374^{* * *} \\
(0.074)\end{array}$ & $\begin{array}{l}0.371^{* * *} \\
(0.074)\end{array}$ & $\begin{array}{l}0.315^{* * *} \\
(0.075)\end{array}$ \\
\hline Other & $\begin{array}{l}0.199^{+} \\
(0.115)\end{array}$ & $\begin{array}{l}0.215^{+} \\
(0.115)\end{array}$ & $\begin{array}{c}0.182 \\
(0.116)\end{array}$ \\
\hline $\begin{array}{l}\text { Parent's education }[<\mathrm{HS}] \\
\text { High school graduate }\end{array}$ & $\begin{array}{l}0.232^{* * *} \\
(0.073)\end{array}$ & $\begin{array}{l}0.218^{* *} \\
(0.073)\end{array}$ & $\begin{array}{l}0.208^{* *} \\
(0.073)\end{array}$ \\
\hline Some college & $\begin{array}{c}0.767^{* * *} \\
(0.078)\end{array}$ & $\begin{array}{c}0.741^{* * *} \\
(0.079)\end{array}$ & $\begin{array}{c}0.717^{* * *} \\
(0.079)\end{array}$ \\
\hline College graduate & $\begin{array}{l}1.378^{* * * *} \\
(0.102)\end{array}$ & $\begin{array}{c}1.336^{* * *} \\
(0.102)\end{array}$ & $\begin{array}{l}1.291^{* * *} \\
(0.103)\end{array}$ \\
\hline Respondent poor health & $\begin{array}{c}-0.238^{* *} \\
(0.091)\end{array}$ & $\begin{array}{c}-0.208^{*} \\
(0.091)\end{array}$ & $\begin{array}{c}-0.190^{*} \\
(0.092)\end{array}$ \\
\hline Respondent mental health & $\begin{array}{c}0.034 \\
(0.045)\end{array}$ & $\begin{array}{c}0.019 \\
(0.045)\end{array}$ & $\begin{array}{c}0.028 \\
(0.046)\end{array}$ \\
\hline Household income (ln) & $\begin{array}{c}0.245^{* * *} \\
(0.035)\end{array}$ & $\begin{array}{c}0.238^{* * *} \\
(0.035)\end{array}$ & $\begin{array}{c}0.231 \text { *** } \\
(0.035)\end{array}$ \\
\hline Respondent GPA & $\begin{array}{c}0.845^{* * *} \\
(0.036)\end{array}$ & $\begin{array}{c}0.834^{* * *} \\
(0.036)\end{array}$ & $\begin{array}{c}0.819^{* * *} \\
(0.036)\end{array}$ \\
\hline Time spent with parents & & $\begin{array}{c}0.088^{* * *} \\
(0.013)\end{array}$ & $\begin{array}{c}0.087^{* * *} \\
(0.013)\end{array}$ \\
\hline Parent smokes in $\mathrm{HH}$ & & & $\begin{array}{c}-0.261 \text { *** } \\
(0.056)\end{array}$ \\
\hline Parent obese in $\mathrm{HH}$ & & & $\begin{array}{c}0.014 \\
(0.065)\end{array}$ \\
\hline Intercept & $\begin{array}{c}-1.592^{* * * *} \\
(0.449)\end{array}$ & $\begin{array}{c}-2.035^{* * * *} \\
(0.455)\end{array}$ & $\begin{array}{c}-1.756^{* * * *} \\
(0.459)\end{array}$ \\
\hline \multicolumn{4}{|l|}{ Standard errors in parentheses } \\
\hline \multicolumn{4}{|l|}{${ }^{+} p<.10$} \\
\hline${ }^{*} p<.05$ & & & \\
\hline
\end{tabular}


*** $p<.01$

**** $p<.001$ 
Table 4

Logistic regression estimates: the association between parental health and the likelihood of graduating from college among college attendees $(n=10,280)$.

\begin{tabular}{|c|c|c|c|}
\hline & (1) & (2) & (3) \\
\hline Poor parental health & $\begin{array}{l}-0.208^{*} \\
(0.082)\end{array}$ & $\begin{array}{l}-0.205^{*} \\
(0.082)\end{array}$ & $\begin{array}{l}-0.171^{*} \\
(0.083)\end{array}$ \\
\hline Parent's age & $\begin{array}{l}0.036^{* * *} \\
(0.004)\end{array}$ & $\begin{array}{l}0.036^{* * * *} \\
(0.004)\end{array}$ & $\begin{array}{l}0.034^{* * * *} \\
(0.004)\end{array}$ \\
\hline Number of children in $\mathrm{HH}$ & $\begin{array}{c}0.000 \\
(0.019)\end{array}$ & $\begin{array}{c}0.002 \\
(0.019)\end{array}$ & $\begin{array}{l}-0.001 \\
(0.019)\end{array}$ \\
\hline Single parent household & $\begin{array}{l}-0.014 \\
(0.062)\end{array}$ & $\begin{array}{l}-0.018 \\
(0.063)\end{array}$ & $\begin{array}{l}-0.009 \\
(0.063)\end{array}$ \\
\hline Male respondent & $\begin{array}{c}-0.133^{* *} \\
(0.050)\end{array}$ & $\begin{array}{l}-0.111^{*} \\
(0.051)\end{array}$ & $\begin{array}{l}-0.117^{*} \\
(0.051)\end{array}$ \\
\hline Respondent's age & $\begin{array}{c}0.014 \\
(0.014)\end{array}$ & $\begin{array}{c}0.015 \\
(0.014)\end{array}$ & $\begin{array}{c}0.017 \\
(0.014)\end{array}$ \\
\hline $\begin{array}{l}\text { Respondent's race [NH White] } \\
\text { NH Black }\end{array}$ & $\begin{array}{c}0.424^{* * *} \\
(0.066)\end{array}$ & $\begin{array}{c}0.423^{* * *} \\
(0.066)\end{array}$ & $\begin{array}{c}0.401^{* * *} \\
(0.066)\end{array}$ \\
\hline Hispanic & $\begin{array}{l}0.370^{* * *} \\
(0.078)\end{array}$ & $\begin{array}{l}0.371^{* * *} \\
(0.078)\end{array}$ & $\begin{array}{l}0.334^{* * *} \\
(0.078)\end{array}$ \\
\hline Other & $\begin{array}{c}0.019 \\
(0.095)\end{array}$ & $\begin{array}{c}0.036 \\
(0.095)\end{array}$ & $\begin{array}{l}-0.016 \\
(0.096)\end{array}$ \\
\hline $\begin{array}{l}\text { Parent's education }[<\mathrm{HS}] \\
\text { High school graduate }\end{array}$ & $\begin{array}{l}0.275^{* *} \\
(0.095)\end{array}$ & $\begin{array}{l}0.265^{* * *} \\
(0.096)\end{array}$ & $\begin{array}{c}0.272^{* * *} \\
(0.096)\end{array}$ \\
\hline Some college & $\begin{array}{c}0.471^{* * *} \\
(0.095)\end{array}$ & $\begin{array}{c}0.455^{* * *} \\
(0.095)\end{array}$ & $\begin{array}{c}0.456^{* * *} \\
(0.095)\end{array}$ \\
\hline College graduate & $\begin{array}{c}1.055^{* * * *} \\
(0.099)\end{array}$ & $\begin{array}{c}1.032^{* * * *} \\
(0.100)\end{array}$ & $\begin{array}{c}1.015^{* * *} \\
(0.100)\end{array}$ \\
\hline Respondent poor health & $\begin{array}{c}-0.514^{* * * *} \\
(0.116)\end{array}$ & $\begin{array}{c}-0.503^{* * * *} \\
(0.116)\end{array}$ & $\begin{array}{c}-0.479^{\text {**** }} \\
(0.116)\end{array}$ \\
\hline Respondent mental health & $\begin{array}{l}-0.034 \\
(0.045)\end{array}$ & $\begin{array}{l}-0.045 \\
(0.045)\end{array}$ & $\begin{array}{l}-0.033 \\
(0.045)\end{array}$ \\
\hline Household income (ln) & $\begin{array}{c}0.455^{* * *} \\
(0.041)\end{array}$ & $\begin{array}{c}0.451 \\
(0.041)\end{array}$ & $\begin{array}{c}0.438^{* * * *} \\
(0.041)\end{array}$ \\
\hline Respondent GPA & $\begin{array}{l}1.591^{* * * *} \\
(0.042)\end{array}$ & $\begin{array}{c}1.584^{* * *} \\
(0.042)\end{array}$ & $\begin{array}{c}1.575^{* * *} \\
(0.042)\end{array}$ \\
\hline Time spent with parents & & $\begin{array}{c}0.047^{* * *} \\
(0.012)\end{array}$ & $\begin{array}{c}0.047^{* * *} \\
(0.012)\end{array}$ \\
\hline Parent smokes in $\mathrm{HH}$ & & & $\begin{array}{c}-0.272^{* * * *} \\
(0.060)\end{array}$ \\
\hline Parent obese in $\mathrm{HH}$ & & & $\begin{array}{c}-0.208^{* * * *} \\
(0.061)\end{array}$ \\
\hline Intercept & $\begin{array}{c}-9.015^{* * * *} \\
(0.469)\end{array}$ & $\begin{array}{c}-9.218^{* * *} \\
(0.473)\end{array}$ & $\begin{array}{c}-8.989^{\text {**** }} \\
(0.475)\end{array}$ \\
\hline \multicolumn{4}{|l|}{ Standard errors in parentheses } \\
\hline \multicolumn{4}{|l|}{${ }^{+} p<.10$} \\
\hline \multicolumn{4}{|l|}{${ }^{*} p<.05$} \\
\hline${ }^{* *} p<.01$ & & & \\
\hline
\end{tabular}


*** $p<.001$ 
Table 5

Estimated probability of educational attainment level as a function of parental health status

\begin{tabular}{lcccc}
\hline & Probability & Odds & Odds Ratio & $\ln ($ odds ratio) \\
\hline Parental Health Status & \multicolumn{4}{c}{ Graduating High School } \\
Fair, Poor & 0.957 & 22.499 & \\
Excellent, Very good, Good & 0.964 & 26.944 & 0.835 & -0.180 \\
& \multicolumn{4}{c}{ Attending College High School Graduates } \\
Fair, Poor & 0.842 & 5.344 & \\
Excellent, Very good, Good & 0.855 & 5.893 & 0.907 & -0.098 \\
& Graduating from College among College Attendees \\
Fair, Poor & 0.325 & 0.482 & & \\
Excellent, Very good, Good & 0.364 & 0.572 & 0.843 & -0.171 \\
\hline
\end{tabular}

Note: Estimates derived from Model 3 in Tables 2-4. 